\title{
Unconventional sexual behaviors and their associations with physical, mental and sexual health parameters: a study in 18 large Brazilian cities
}

\section{Comportamentos sexuais não convencionais e associações com parâmetros de saúde física, mental e sexual: um estudo em 18 grandes cidades brasileiras}

\author{
Waldemar Mendes de Oliveira Júnior, ${ }^{1}$ Carmita Helena Najjar Abdo ${ }^{2,3}$ \\ ${ }^{1}$ Institute of Psychiatry, Hospital das Clínicas, School of Medicine, Universidade de São Paulo (USP), São Paulo, SP, Brazil \\ ${ }^{2}$ Department of Psychiatry, School of Medicine, Universidade de São Paulo (USP), São Paulo, SP, Brazil \\ ${ }^{3}$ Program of Studies in Sexuality (ProSex), Institute of Psychiatry, Hospital das Clínicas, School of Medicine, Universidade de São Paulo (USP), \\ São Paulo, SP, Brazil
}

\begin{abstract}
Objective: There have been many studies investigating paraphilias and sexual compulsion, but thus far little data about prevalence of unusual sexual practices that are subthreshold for these diagnoses. The associations between unconventional sexual behavior and sociodemographic and health parameters were investigated. Method: A cross-sectional study of 7,022 individuals ( $45.4 \%$ of women) was carried out using a selfadministered questionnaire that compared individuals carrying at least one reference of unconventional sexual behavior (group 1) with individuals without such reference (group 2). Results: Women's mean age was 35.0 vs. 35.9 years $(\mathrm{p}<0.05)$ and men's mean age was 36.5 vs. 37.8 years ( $\mathrm{p}$ $<0.05)$ being lower in group 1 than in group 2, respectively. More men $(52.3 \%)$ than women $(30.4 \%)(\mathrm{p}<0.001)$ presented unconventional sexual behavior. Fetishism (13.4\%) and voyeuristic behavior (13.0\%) were more frequent. Unconventional sexual behavior was associated with male gender, single or separated marital status, black or mulatto race, elementary and high school educational level, history of posttraumatic stress disorder treatment, alcohol dependence, emergency contraception, difficulty at the beginning of sexual life, sexual violence, bisexuality, and performance of anal or oral intercourse. Conclusion: Unconventional sexual behaviors are important because they are associated with poorer health status and lower educational levels.
\end{abstract}

Descriptors: Sexual behavior; Sexuality; Paraphilias; Unsafe sex; Sexual partners

\section{Resumo}

Objetivo: Pesquisadores têm conduzido vários estudos relacionados a parafilias e compulsão sexual, mas há poucos dados sobre a prevalência de práticas sexuais não usuais que são subliminares para estes diagnósticos. Foi investigada a associação entre comportamento sexual não convencional e parâmetros sociodemográficos e de saúde. Método: Estudo transversal, de 7.022 indivíduos (54,6\% de homens), realizado por meio de questionário autorresponsivo, comparou individuos com pelo menos um comportamento sexual não convencional (grupo 1) e individuos sem esta referência (grupo 2). Resultados: A idade média das mulheres (35,0 vs. $35,9$ anos; $p<0,05)$ e dos homens (36,5 vs. 37,8 anos; $p<0,05)$ foi menor no grupo 1 do que no grupo 2, respectivamente. Mais homens (52,3\%) que mulheres $(30,4 \%)(p<0,001)$ apresentaram comportamento sexual não convencional. Comportamento fetichista (13,4\%) e voyeurista (13,0\%) foram os mais frequentes. Comportamento sexual não convencional foi associado com: gênero masculino; estado civil solteiro e separado; raça negra e parda; nivel educacional médio e fundamental; histórico de tratamento para transtorno do estresse pós-traumático; dependência por álcool; contracep̧̧ão de emergência; dificuldade no início da vida sexual; violência sexual sofrida; bissexualidade; e prática de sexo anal e oral. Conclusäo: Os comportamentos sexuais não convencionais são importantes porque estão associados a piores condiçôes de saúde e a baixo nivel educacional.

Descritores: Comportamento sexual; Sexualidade; Parafilia; Sexo sem proteção; Parceiros sexuais

\section{Introduction}

So-called conventional sexual behaviors involve sexual intercourse between two living adults, whose aim is to provide pleasure and/or to procreate. ${ }^{1}$
Unconventional sexual behaviors (USBs) are represented by different preferences regarding one's sexual object, partner's age or nature of sexual activity. USBs that are engaged in frequently and
Submitted: July 11, 2009

Accepted: October 27, 2009
Correspondence

Waldemar Mendes de Oliveira Júnior Rua Capote Valente, 432 conjunto 125 05409-001 Pinheiros

São Paulo - SP

Fax and telephone: +55 11 3062-7915

E-mail: oliveirajrwald@uol.com.br 
that cause clinically significant distress or disability are sometimes classified as paraphilias and paraphilia-related disorders (PRD). ${ }^{2}$

As opposed to what might be expected, USBs are not so rare in the general population. According to the U.S. study National Health and Social Life Study (US NHSLS), 46\% of young men and $28 \%$ of older men admit that group sex is an attractive idea, while these rates are lower both among young women (9\%) and older women $(5 \%){ }^{3}$

A large Australian study conducted in 1998 with 3,039 male volunteers interviewed by telephone who had practised homosexual activity in the previous six months found that $12 \%$ had had sexual intercourse that included sadomasochism, and $36 \%$ had had group sex. ${ }^{4}$ In addition, another Australian study revealed that unconventional sexual activities, such as group sex and sadomasochism among male homosexuals, exposed these individuals to a higher risk of acquiring HIV.

This study, based on the cross-sectional study "Brazilian Sexual Life Study" (BSLS), aimed at characterizing sociodemographic, physical, mental and sexual health parameters of individuals that practise or have practised one or more USBs throughout their lives. ${ }^{5}$ This article is not concerned with determining what is "normal" or "not normal" in sexual behavior. Its focus is on individuals that reported current or previous practice of sexual behaviors considered unconventional by the specialized literature. ${ }^{1}$ Such unconventional behaviors will often be subthreshold for clinically diagnosable sexual disorders (e.g., paraphilias and PRDs), either in the DSM-IV-TR or the ICD-10.,

The characterization of physical, mental and sexual health parameters in individuals who do or do not engage in USBs can contribute to the implementation of prevention and treatment measures when such behaviors are dysfunctional in a given individual, i.e., in paraphilias and PRDs. In addition, it can help to show how USBs manifest in the general population.

\section{Method}

The sample was obtained from the cross-sectional study BSLS, which was conducted from November 2002 to February 2003. It comprised a total of 7,022 individuals $(54.6 \%$ men and $45.4 \%$ women), aged 18 years or over from 18 cities in 13 Brazilian states. ${ }^{5}$ Individuals from the five macroregions in Brazil were recruited, although such recruitment was not performed by sample calculation because participation was voluntary.

The cities included in the sample were: Southeast Region: São Paulo-SP, São Caetano-SP, Campinas-SP, Santos-SP, São BernardoSP, Diadema-SP, Rio de Janeiro-RJ, and Belo Horizonte-MG; South Region: Curitiba-PR, Porto Alegre-RS, and FlorianópolisSC; North Region: Belém-PA; Midwest Region: Campo GrandeMS and Brasília-DF; Northeast Region: Salvador-BA, Recife-PE, Fortaleza-CE, and Natal-RN.

The individuals were weekend passers-by in beaches, parks and shopping malls, and were invited to complete an anonymous and self-administered questionnaire. The procedure used for data collection consisted in inviting the individuals to answer the questionnaire. The researchers approached the subjects, introduced themselves in a friendly manner and informed them that the study was about sexuality and sexual life. The interviewers were wearing a white coat. All of them underwent training before administering the questionnaire. Training included general information and debate on the best method of approaching the participants. The need to provide the subjects with privacy to complete the questionnaire and to make sure that the questionnaires were adequately stored in order to guarantee anonymity was also discussed.

The locations where the researchers approached the individuals were very busy, with, it was hoped, a varied mix of people. Those who refused to complete the questionnaire were not asked the reason for their refusal. Inclusion criteria were being literate; being 18 years or over; and agreeing to complete the questionnaire. Exclusion criteria were being illiterate; being drunk or with signs of intoxication by psychoactive substances; and those who were in doubt about participating in the survey.

There was an isolated site where the individuals could complete the questionnaire without interference from the researchers, who kept a reasonable distance from the participants. Such a measure was enough to avoid embarrassment and, at the same time, enable the researchers to ensure that the participants received no help from others in answering the questions. The instrument did not ask for personal data, that is, it was an anonymous questionnaire, and this was explained to the participants at the outset. These actions were taken to reduce the subjects' embarrassment when answering questions about their sexuality.

The original questionnaire was pilot tested in 30 individuals (men and women). After being adapted, it was comprised of 87 items, divided into five sections: sociodemographic aspects; life habits; sexual behavior, history and orientation; general health; and sexual difficulties. ${ }^{5}$

This study was approved by the Research Ethics Committee of Hospital das Clínicas, School of Medicine, Universidade de São Paulo.

The authors focused on the study of the 10 USBs most frequently found in the literature: group sex, ménage a trois, swinging, incestuous sexual intercourse, sexual practices with animals, fetishes, exchange of foul language or aggression, being paid for sex and sexual arousal using exhibitionist or voyeuristic activities.

The sample was divided into two groups for comparative analysis: Group 1 - individuals who reported at least one of the USBs being studied throughout their lives (without specifying the number of times such behaviors were practised). Group $2-$ individuals who reported never having had any of these behaviors throughout their lives.

Of the total sample, 1,271 (18.1\%) individuals left at least one item unanswered in questions related to presence or absence of USB and were excluded from the analysis. A comparison was performed between respondents and non-respondents to determine differences between both groups. 
Groups 1 and 2 were compared with regard to sociodemographic aspects and physical, mental and sexual health parameters. The chi-square test was used for categorical variables, and Student's $t$ test for numeric variables. Statistical associations showing $\mathrm{p} \leq 0.05$ were considered significant.

Independent variables that had statistically significant association with presence of USB were selected. The method went from a simpler to a more complex logistic regression model. Therefore, independent variables were included one by one and only those that maintained statistical significance ( $\mathrm{p} \leq 0.05)$ after inclusion of the other variables remained in the final model, in addition to those that could have the coefficients of independent variables $(\beta)$ adjusted in at least $10 \%$. The variables that did not meet these requirements were excluded from the final model. Therefore, the final logistic regression model simultaneously included the variables and the odd ratios that resulted from the statistical interaction among the variables.

\section{Results}

Of the total sample, $52.3 \%$ of men and $30.4 \%$ of women had practised at least one of the 10 USBs being studied throughout their lives. Twenty percent of the sample reported having practised only one of the 10 USBs. Individuals that had practised more than one of the USBs were not commonly found. Only $9.4 \%$ of the sample reported having practised two USBs. The frequency for three, four and five USBs was even lower (5.0, 2.5 and 1.1\%, respectively).

The most frequently reported USBs were fetishist and voyeuristic behaviors, which had very similar percentages. The least reported activities were sex with animals and swinging. Table 1 shows these numbers.

Frequency of USB was higher in the Midwest (49.9\%) and Northeast (49.3\%). The Southeast was the region with the lowest prevalence (39.6\%). For the other regions, frequencies were intermediate between the previous regions and nearly identical between themselves: $42.1 \%$ in the North and $42.4 \%$ in the South $(\mathrm{p}<0.001)$.

Mean age in group 1 (practise of USB) was lower than that of group 2 (no reference to USB) both for men and women. Mean age of men in group 1 was 36.5 years $(S D=13.5)$, whereas it was 37.8 years in group $2(S D=13.7)(p<0.01)$. Mean age of

Table 1 - Distribution of number (No.) and percentage (\%) of individuals, according to type of unconventional sexual behavior at least once throughout life. Brazil, 2003

\begin{tabular}{lcc}
\hline \multicolumn{1}{c}{ Sexual behavior } & No. & $\%$ \\
\hline Fetish & 778 & 13.4 \\
Voyeurism & 754 & 13.0 \\
Incest & 649 & 11.3 \\
Menage à trois & 622 & 10.9 \\
Exhibitionism & 535 & 9.3 \\
Sadomasochism & 523 & 9.0 \\
Group sex & 443 & 7.7 \\
Money in exchange for sex & 274 & 4.8 \\
Sexual practice with animals & 181 & 3.2 \\
Swinging & 174 & 3.1 \\
\hline
\end{tabular}

women in group 1 was 35.0 years $(S D=12.6)$, whereas it was 35.9 years in group $2(S D=13.0)(p<0.01)$. Table 2 compares the sociodemographic characteristics of both groups.

When comparing the Brazilian population to our sample, we realized that this sample is constituted of individuals with a higher educational level. For instance, $57.8 \%$ of the women and $52.4 \%$ of the men had a university degree, whereas these figures for the Brazilian population are, respectively, $7.0 \%$ and $6.5 \%$. Similarly to the Brazilian population (42.6\%), most of the individuals in this sample lived in the Southeast region of the country $(56.0 \%)$, and this region revealed the lowest frequency of USBs. In terms of gender, different from the Brazilian population ( $49.2 \%$ of men and $50.8 \%$ of women), our sample presented a higher frequency of males $(54.6 \%)$ than females $(45.4 \%)$, that is, men agreed to participate in the study more frequently than women. ${ }^{8}$ Therefore, this sample can be considered a partial representation of the Brazilian population, even if the present study was not intended to generalize these data to the Brazilian population as a whole.

There was no statistically significant association between clinical conditions such as diabetes and hypertension and USB. There were negative indications of physical health and sexual risk behavior in the sample with USB, namely higher frequency of AIDS (only for men) and STD (for men and women). In women, history of uterine cancer treatment was significantly associated with USB. Some negative mental health conditions were also associated with USB. There was association between posttraumatic stress disorder, alcohol dependence, use of alcohol, drugs and tobacco and USB both for men and women. Treatment for tobacco dependence was associated with USB only for men, whereas treatment for drug dependence had an association for women only (Table 3).

Age at the beginning of sexual life was younger in group 1 than in group 2 ( 18.5 years vs. 19.5 years; $\mathrm{p}<0.001$ for women and 15.5 years vs. 16.4 years; $\mathrm{p}<0.001$ for men). The frequency of USB in women who reported loss of concentration during sexual activity was $35.1 \%$, compared to $28.9 \%$ in those who did not report such condition $(\mathrm{p}<0.01)$. For men, these values were, respectively, 60.3 vs. $49.9 \%$ ( $\mathrm{p}<0.001)$.

USB rates were $35.4 \%$ for women who reported loss of sexual pleasure during sexual activity, compared to $29.6 \%$ for those who did not report it $(\mathrm{p}<0.05)$. For men, these values were, respectively, 62.1 vs. $50.7 \%(\mathrm{p}<0.001)$.

Lack of sexual desire and orgasmic disorder were not statistically associated with USB both for men and women. However, men with erection difficulties reported USB in $55.8 \%$ of cases, whereas men with no such difficulty reported it in $50.2 \%$ of cases $(\mathrm{p}<0.01)$.

For both genders, individuals with up to seven weekly orgasms had a $41.7 \%$ incidence of USB, whereas the prevalence was $58.2 \%$ ( $\mathrm{p}<0.001)$ for those with more than seven weekly orgasms. History of emergency contraception (use of the "morning after pill") and report of extra-marital relationships were associated with USB. Women with history of emergency contraception reported USB in $43.2 \%$ of cases vs. $26.7 \%$ of those with no such history 
Table 2 - Distribution of number (No.) and percentage (\%) of men and women, according to sociodemographic and unconventional sex aspects. Brazil, 2003

\begin{tabular}{|c|c|c|c|c|c|c|}
\hline \multirow{3}{*}{$\begin{array}{c}\text { Sociodemographic } \\
\text { aspects }\end{array}$} & \multirow[t]{3}{*}{ Sex } & \multicolumn{4}{|c|}{ Unconventional sex } & \multirow[t]{3}{*}{$p$-value } \\
\hline & & \multicolumn{2}{|c|}{ No } & \multicolumn{2}{|c|}{ Yes } & \\
\hline & & No. & $\%$ & No. & $\%$ & \\
\hline \multirow[t]{12}{*}{ Age group (years) } & Women & & & & & 0.002 \\
\hline & up to 25 & 508 & 71.1 & 206 & 28.9 & \\
\hline & $26-40$ & 625 & 65.4 & 330 & 34.6 & \\
\hline & $41-60$ & 571 & 73.7 & 204 & 26.3 & \\
\hline & 61 or older & 69 & 67.6 & 33 & 32.4 & \\
\hline & Total & 1773 & 69.6 & 773 & 30.4 & \\
\hline & Men & & & & & 0.013 \\
\hline & up to 25 & 317 & 42.7 & 426 & 57.3 & \\
\hline & $26-40$ & 608 & 48.3 & 650 & 51.7 & \\
\hline & $41-60$ & 464 & 50.2 & 460 & 49.8 & \\
\hline & 61 or older & 106 & 50.5 & 104 & 49.5 & \\
\hline & Total & 1495 & 47.7 & 1640 & 52.3 & \\
\hline \multirow[t]{12}{*}{ Race } & Women & & & & & 0.003 \\
\hline & Caucasian & 1433 & 71.5 & 571 & 28.5 & \\
\hline & Black & 79 & 62.2 & 48 & 37.8 & \\
\hline & Biracial (Caucasian /Black) & 198 & 64.1 & 111 & 35.9 & \\
\hline & Others & 71 & 62.8 & 42 & 37.2 & \\
\hline & Total & 1781 & 69.8 & 772 & 30.2 & \\
\hline & Men & & & & & $<0.001$ \\
\hline & Caucasian & 1140 & 49.3 & 1170 & 50.7 & \\
\hline & Black & 94 & 40.8 & 136 & 59.2 & \\
\hline & Biracial (Caucasian /Black) & 199 & 40.8 & 288 & 59.2 & \\
\hline & Others & 67 & 60.3 & 44 & 39.7 & \\
\hline & Total & 1500 & 47.8 & 1638 & 52.2 & \\
\hline \multirow[t]{14}{*}{ Marital status } & Women & & & & & $<0.001$ \\
\hline & Married & 677 & 76.7 & 205 & 23.3 & \\
\hline & Living with partner & 176 & 60.9 & 113 & 39.1 & \\
\hline & Single & 701 & 68.5 & 322 & 31.5 & \\
\hline & Divorced & 185 & 61.4 & 116 & 38.6 & \\
\hline & Widow & 50 & 64.9 & 27 & 35.1 & \\
\hline & Total & 1789 & 69.6 & 783 & 30.4 & \\
\hline & Men & & & & & $<0.001$ \\
\hline & Married & 689 & 53.3 & 603 & 46.7 & \\
\hline & Living with partner & 164 & 46.2 & 191 & 53.8 & \\
\hline & Single & 527 & 43.6 & 680 & 56.3 & \\
\hline & Divorced & 110 & 39.4 & 169 & 60.6 & \\
\hline & Widower & 14 & 53.8 & 12 & 46.2 & \\
\hline & Total & 1504 & 47.6 & 1655 & 52.4 & \\
\hline \multirow[t]{10}{*}{ Educational level } & Women & & & & & $<0.001$ \\
\hline & Higher & 1068 & 72.2 & 411 & 27.8 & \\
\hline & High school & 603 & 68.6 & 276 & 31.4 & \\
\hline & Elementary & 112 & 55.7 & 89 & 44.3 & \\
\hline & Total & 1783 & 69.7 & 776 & 30.3 & \\
\hline & Men & & & & & 0.002 \\
\hline & Higher & 826 & 49.9 & 827 & 50.1 & \\
\hline & High school & 536 & 46.4 & 619 & 53.6 & \\
\hline & Elementary & 139 & 40.0 & 208 & 60.0 & \\
\hline & Total & 1501 & 47.6 & 1654 & 52.4 & \\
\hline
\end{tabular}

( $\mathrm{p}<0.001)$. Women who reported extra-marital relationships had the following USB rates: 66.1 vs. $34.7 \%$ for those without such history, $(\mathrm{p}<0.001)$. For men, rates were 72.1 and $55.1 \%$, respectively $(\mathrm{p}<0.001)$.
Women who reported induced abortion had USB in $42.3 \%$ of cases vs. $26.8 \%$ of those with no such history $(\mathrm{p}<0.001)$. Individuals with USB had higher mean number of partners over the past 12 months. Women, respectively, in groups 1 and 2 had 
Table 3 - Distribution of number (No.) and percentage (\%) of men and women, according to reported health condition and unconventional sex. Brazil, 2003

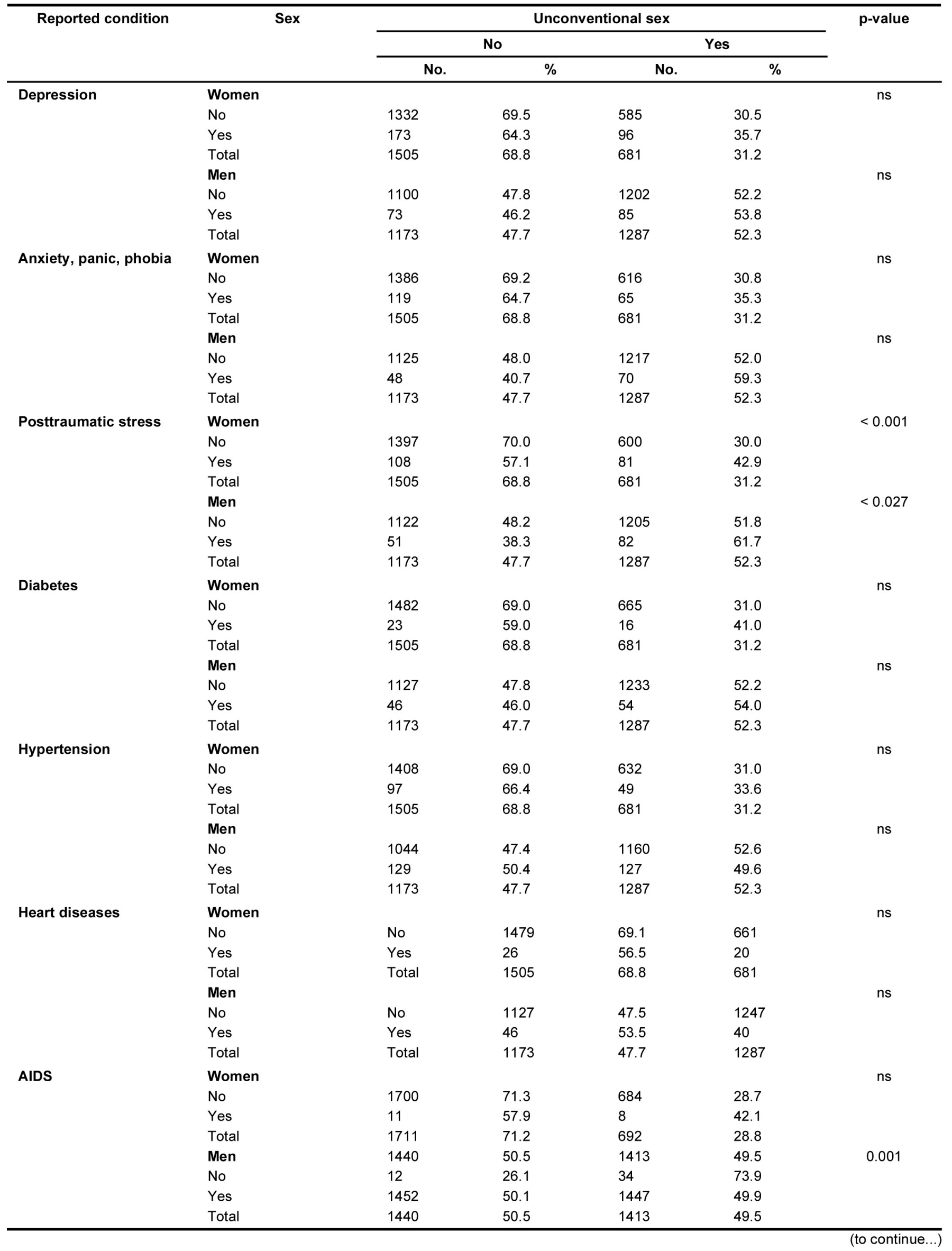


(Continuation)

\begin{tabular}{|c|c|c|c|c|c|c|}
\hline \multirow[t]{3}{*}{ Reported condition } & \multirow[t]{3}{*}{ Sex } & \multicolumn{4}{|c|}{ Unconventional sex } & \multirow[t]{3}{*}{ p-value } \\
\hline & & \multicolumn{2}{|c|}{ No } & \multicolumn{2}{|c|}{ Yes } & \\
\hline & & No. & $\%$ & No. & $\%$ & \\
\hline \multirow[t]{8}{*}{ STD } & Women & & & & & $<0.001$ \\
\hline & No & No & 1616 & 72.5 & 614 & \\
\hline & Yes & Yes & 144 & 54.3 & 121 & \\
\hline & Total & Total & 1760 & 70.5 & 735 & \\
\hline & Men & & & & & $<0.001$ \\
\hline & No & 1309 & 52.8 & 1168 & 47.2 & \\
\hline & Yes & 179 & 31.4 & 391 & 68.6 & \\
\hline & Total & 1488 & 48.8 & 1559 & 51.2 & \\
\hline \multirow{8}{*}{$\begin{array}{l}\text { Treatment for } \\
\text { alcohol dependence }\end{array}$} & Women & & & & & 0.001 \\
\hline & No & 1504 & 69.1 & 674 & 30.9 & \\
\hline & Yes & 1 & 12.5 & 7 & 87.5 & \\
\hline & Total & 1505 & 68.8 & 681 & 31.2 & \\
\hline & Men & & & & & 0.024 \\
\hline & No & 1153 & 48.0 & 1247 & 52.0 & \\
\hline & Yes & 20 & 33.3 & 40 & 66.7 & \\
\hline & Total & 1173 & 47.7 & 1287 & 52.3 & \\
\hline \multirow{8}{*}{$\begin{array}{l}\text { Treatment for } \\
\text { tobacco dependence }\end{array}$} & Women & & & & & ns \\
\hline & No & 1480 & 69.0 & 665 & 31.0 & \\
\hline & Yes & 25 & 61.0 & 16 & 39.0 & \\
\hline & Total & 1505 & 68.8 & 681 & 31.2 & \\
\hline & Men & & & & & 0.009 \\
\hline & No & 1154 & 48.1 & 1245 & 51.9 & \\
\hline & Yes & 19 & 31.1 & 42 & 68.9 & \\
\hline & Total & 1173 & 47.7 & 1287 & 52.3 & \\
\hline
\end{tabular}

1.7 vs. 1.2 partners, $(\mathrm{p}<0.001)$ and men had 3.5 vs. 2.0 partners, $(\mathrm{p}<0.001)$. Mean occurrence of weekly sexual intercourse was higher in group 1 than in group 2 (2.6 vs. 2.3 , respectively; $\mathrm{p}<$ 0.001 for women and 3.4 vs. 3.0; $<<0.001$ for men).

USB was present in $38.3 \%$ of women who reported fear of contracting STD vs. $28.4 \%$ ( $<<0.001)$ for those who did not report such fear. Rates for men were respectively 61.1 and $47.9 \%$ ( $<<0.001)$.

Table 4 shows aspects regarding sexual practice and history, and Table 5 shows the results of the final multivariate logistic regression model.

Table 6 analyzed the data, stratifying individuals according to number of previously performed different unconventional sexual practices and according to some sociodemographic variables.

Comparison between individuals who answered all questionnaire items on USB and those who left at least one of these items unanswered showed that most non-respondents had the following characteristics: female; widow, married and living with partner; Protestant religion; lower educational level; black race; and Southeast Region. They were usually older individuals and with no history of sexual violence (data not shown).

\section{Discussion}

The BSLS sample includes all five Brazilian regions. Despite the lack of sample calculation and stratification of socioeconomic classes and other sociodemographic variables, this study can be used as an instrument for further research with calculated samples. The likely selection bias does not diminish the merit of the study, since there was no intention of generalizing these data for the entire Brazilian population. It is estimated that frequency of USB in this sample can be underestimated, as individuals that were excluded from the analysis had more sociodemographic aspects positively associated with USB. Another reason that may have caused the underestimation of the data is reluctance to admit to deviant behaviors. People who are more sex-positive and experienced tend to answer questionnaires about sexuality more often than those less interested in sex. In the present study, it is not possible to establish how many individuals refused to answer the questionnaire due to shame or other reasons. ${ }^{9}$

Voyeuristic and exhibitionistic behaviors were found in $13.0 \%$ and $9.3 \%$ respectively. Population study conducted with 2,450 randomly selected individuals aged between 18 and 60 year-olds, also showed that the prevalence of voyeuristic behavior $(7.7 \%)$ was higher than that of exhibitionists (3.1\%). ${ }^{10}$ Fetishistic behavior was found in $13.4 \%$ of cases, the most frequent USB in the sample. Study based on the same sample cited above found $2.8 \%$ of men and $0.4 \%$ of women reported at least one episode of transvestic fetishism. The higher prevalence found in our study is probably because we have included any type of fetishistic behavior. ${ }^{11}$ 
Table 4 - Distribution of number (No.) and percentage (\%) of men and women, according to aspects relative to sexual practice and history and unconventional sex. Brazil, 2003

\begin{tabular}{|c|c|c|c|c|c|c|}
\hline \multirow{3}{*}{$\begin{array}{l}\text { Aspects relative to sexual } \\
\text { practice and history }\end{array}$} & \multirow[t]{3}{*}{ Sex } & \multicolumn{4}{|c|}{ Unconventional sex } & \multirow[t]{3}{*}{ p-value } \\
\hline & & \multicolumn{2}{|c|}{ No } & \multicolumn{2}{|c|}{ Yes } & \\
\hline & & No. & $\%$ & No. & $\%$ & \\
\hline \multirow{5}{*}{ Oral sex } & No & 624 & 73.2 & 228 & 26.8 & \\
\hline & Yes & 1086 & 66.7 & 543 & 33.3 & \\
\hline & Total & 1710 & 68.9 & 771 & 31.1 & \\
\hline & Yes & 981 & 47.6 & 1182 & 54.6 & \\
\hline & Total & 1486 & 47.6 & 1634 & 52.4 & \\
\hline \multirow[t]{4}{*}{ Anal sex } & Women & & & & & $<0.001$ \\
\hline & No & 1477 & 71.2 & 597 & 28.8 & \\
\hline & Yes & 228 & 57.0 & 172 & 43.0 & \\
\hline & Total & 1480 & 47.6 & 1629 & 52.4 & \\
\hline \multirow[t]{9}{*}{ Sexual orientation } & Women & & & & & $<0.001$ \\
\hline & Hetero & 1613 & 69.4 & 711 & 30.6 & \\
\hline & Homo & 38 & 66.7 & 19 & 33.3 & \\
\hline & $\mathrm{Bi}$ & 5 & 23.8 & 16 & 76.2 & \\
\hline & Total & 1656 & 68.9 & 746 & 31.1 & \\
\hline & Men & & & & & $<0.001$ \\
\hline & Hetero & 1365 & 48.9 & 1427 & 51.1 & \\
\hline & Homo & 75 & 38.1 & 122 & 61.9 & \\
\hline & $\mathrm{Bi}$ & 11 & 17.7 & 51 & 82.3 & \\
\hline \multirow{2}{*}{$\begin{array}{l}\text { Information about } \\
\text { sex throughout life }\end{array}$} & Yes & 264 & 48.1 & 285 & 51.9 & \\
\hline & Total & 1500 & 47.7 & 1644 & 52.3 & \\
\hline \multirow{8}{*}{$\begin{array}{l}\text { Difficulty at the beginning of } \\
\text { sexual life }\end{array}$} & Women & & & & & $<0.001$ \\
\hline & No & 1036 & 72.4 & 394 & 27.6 & \\
\hline & Yes & 651 & 64.2 & 363 & 35.8 & \\
\hline & Total & 1687 & 69.0 & 757 & 31.0 & \\
\hline & Men & & & & & 0.004 \\
\hline & No & 1092 & 49.4 & 1117 & 50.6 & \\
\hline & Yes & 386 & 43.7 & 498 & 56.3 & \\
\hline & Total & 1478 & 47.8 & 1615 & 52.2 & \\
\hline \multirow[t]{8}{*}{ Victim of sexual violence } & Women & & & & & $<0.001$ \\
\hline & No & 1736 & 72.4 & 663 & 27.6 & \\
\hline & Yes & 58 & 43.6 & 75 & 56.4 & \\
\hline & Total & 1794 & 70.9 & 738 & 29.1 & \\
\hline & Men & & & & & $<0.001$ \\
\hline & No & 1485 & 50.2 & 1471 & 49.8 & \\
\hline & Yes & 10 & 17.5 & 47 & 85.5 & \\
\hline & Total & 1495 & 49.6 & 1518 & 50.4 & \\
\hline
\end{tabular}


Table 5 - Distribution of odds ratios (95\% confidence interval $\mathrm{Cl}$ ) for presence of unconventional sexual behavior, according to independent variables. Brazil. 2003.

\begin{tabular}{|c|c|}
\hline Independent variables & Odds ratio $(95 \% \mathrm{Cl})$ \\
\hline \multicolumn{2}{|l|}{ Gender } \\
\hline Female & 1.00 (reference) \\
\hline Male & $2.30(2.00-2.60)^{* * *}$ \\
\hline \multicolumn{2}{|l|}{ Marital status } \\
\hline Married & 1.00 (reference) \\
\hline Single & $1.20(1.01-1.40)^{*}$ \\
\hline Divorced/separated & $1.40(1.10-1.80)^{* *}$ \\
\hline Widow/widower & $1.00(0.50-1.80)$ \\
\hline \multicolumn{2}{|l|}{ Race } \\
\hline Caucasian & 1.00 (reference) \\
\hline Black & $1.40(1.01-1.90)^{*}$ \\
\hline Mulatto & $1.40(1.10-1.70)^{* \star}$ \\
\hline Other & $1.10(0.80-1.60)$ \\
\hline \multicolumn{2}{|l|}{ Education } \\
\hline Higher & 1.00 (reference) \\
\hline High school & $1.20(1.10-1.50)^{* *}$ \\
\hline Elementary & $1.70(1.30-2.30)^{* * *}$ \\
\hline \multicolumn{2}{|l|}{ Posttraumatic stress } \\
\hline No & 1.00 (reference) \\
\hline Yes & $1.40(1.10-1.80)^{\star}$ \\
\hline \multicolumn{2}{|c|}{ Treatment for alcohol dependence } \\
\hline No & 1.00 (reference) \\
\hline Yes & $2.00(1.10-3.80)^{*}$ \\
\hline \multicolumn{2}{|l|}{ Emergency contraception } \\
\hline No & 1.00 (reference) \\
\hline Yes & $1.80(1.40-2.20)^{\star * *}$ \\
\hline \multicolumn{2}{|l|}{ Difficulty to start sexual life } \\
\hline No & 1.00 (reference) \\
\hline Yes & $1.30(1.20-1.50)^{\star \star \star}$ \\
\hline \multicolumn{2}{|l|}{ Victim of sexual violence } \\
\hline No & 1.00 (reference) \\
\hline Yes & $2.20(1.50-3.20)^{\star * *}$ \\
\hline \multicolumn{2}{|l|}{ Sexual orientation } \\
\hline Heterosexual & 1.00 (reference) \\
\hline Homosexual & $1.40(1.00-1.90)$ \\
\hline Bisexual & $3.60(1.90-6.60)^{\star * \star}$ \\
\hline \multicolumn{2}{|l|}{ Has anal sex } \\
\hline No & 1.00 (reference) \\
\hline Yes & $2.00(1.70-2.30)^{\star * *}$ \\
\hline \multicolumn{2}{|l|}{ Has oral sex } \\
\hline No & 1.00 (reference) \\
\hline Yes & $1.20(1.10-1.50)^{\star \star}$ \\
\hline
\end{tabular}

${ }^{*} p<0.05$

$* * p<0.01$

${ }^{* * *} p<0.001$

We found some similarities between sociodemographic, physical, mental and sexual health factors of paraphilias and PRD and the factors related to the USBs, which does not mean that the USBs can be considered synonyms of paraphilias, PRD or sexual compulsion (SC). However, in the same way as individuals with paraphilias, PRD or SC practise sexual activities that are like those practised by individuals with USBs, they also seem to present similarities regarding sociodemographic aspects and negative health outcomes.

Similarly to paraphilias and SC, there is higher frequency of USBs in men, which was reported by more than half of the respondents. About 1/3 of the women reported this condition. Such a phenomenon can be related to the activity of androgens on sexual desire and interest, ${ }^{12}$ as well as genetic ${ }^{13}$ and cultural influences. However, this is the case for paraphilias and SC, which, as it has been demonstrated, include many USBs analyzed in the present study. We cannot explain the reason for the higher prevalence of USBs in men, but there are some studies demonstrating that unconventional sexual activities, such as group sex, finger stimulation of the anal region, oral stimulation of the anal region ("rimming"), use of vibrators or other fetish objects, sadomasochist games and use of the internet with sexual purposes, are more prevalent among men than among women.,14,15 Studies indicate an association between lower educational level and risky sexual behaviors ${ }^{16}$ and paraphilias, ${ }^{17}$ similar to what was found for individuals with USB.

In a comparison between group 1 men and women (with at least one USB) and men and women who reported more than two USBs, the group of men and women with more than two USBs throughout life is a more homogeneous population: multiple unconventional sexual practices that are lower in older age groups, a period in which sexual activity itself is diminished (see Table 2 and Table 6) ${ }^{18}$

The population practicing USBs was mainly comprised of young individuals that had earlier onset of active sexual life. This is an important period for the formation of the sexual repertoire which is developed in adult life. ${ }^{19}$ It is possible that the earlier onset of sexual life for the individuals who reported a USB means that these individuals are more interested in sex than those of group 2 (who did not report USB).

There was significant association between history of uterine cancer and USB. It is known that compulsive sexual behavior exposes individuals to higher risks of HIV infections and other STDs. ${ }^{20}$ The association between uterine cancer and infection by human papilloma virus (HPV) is also known, as well as the association between HPV infection and risky sexual behavior such as multiple sexual partners and prostitution. ${ }^{21}$ Although it is not possible to confirm diagnosis of uterine cancer, because the data were obtained by a multiple-choice questionnaire, a possible explanation is that USB exposed group 1 women to a higher frequency of STD, among which HPV is possibly present, and to the consequent higher risk of uterine cancer. STDs, including AIDS, are associated with risky sexual behavior, ${ }^{22}$ as well as use of alcohol and drugs. ${ }^{22}$

The individuals of group 1, similarly to the individuals with SC or paraphilias, have a number of psychiatric comorbidities. ${ }^{17,23-25}$ Lack of a validated scale for depression, subclinical depression or lack of knowledge might have led to the absence of significant association in the sample.

We could not find in the literature the prevalence of posttraumatic stress disorder in individuals with USBs; however, 
Table 6 - Distribution of number (No.) and percentage (\%) of men and women, according to sociodemographic aspects and number of unconventional sexual practices. Brazil, 2003

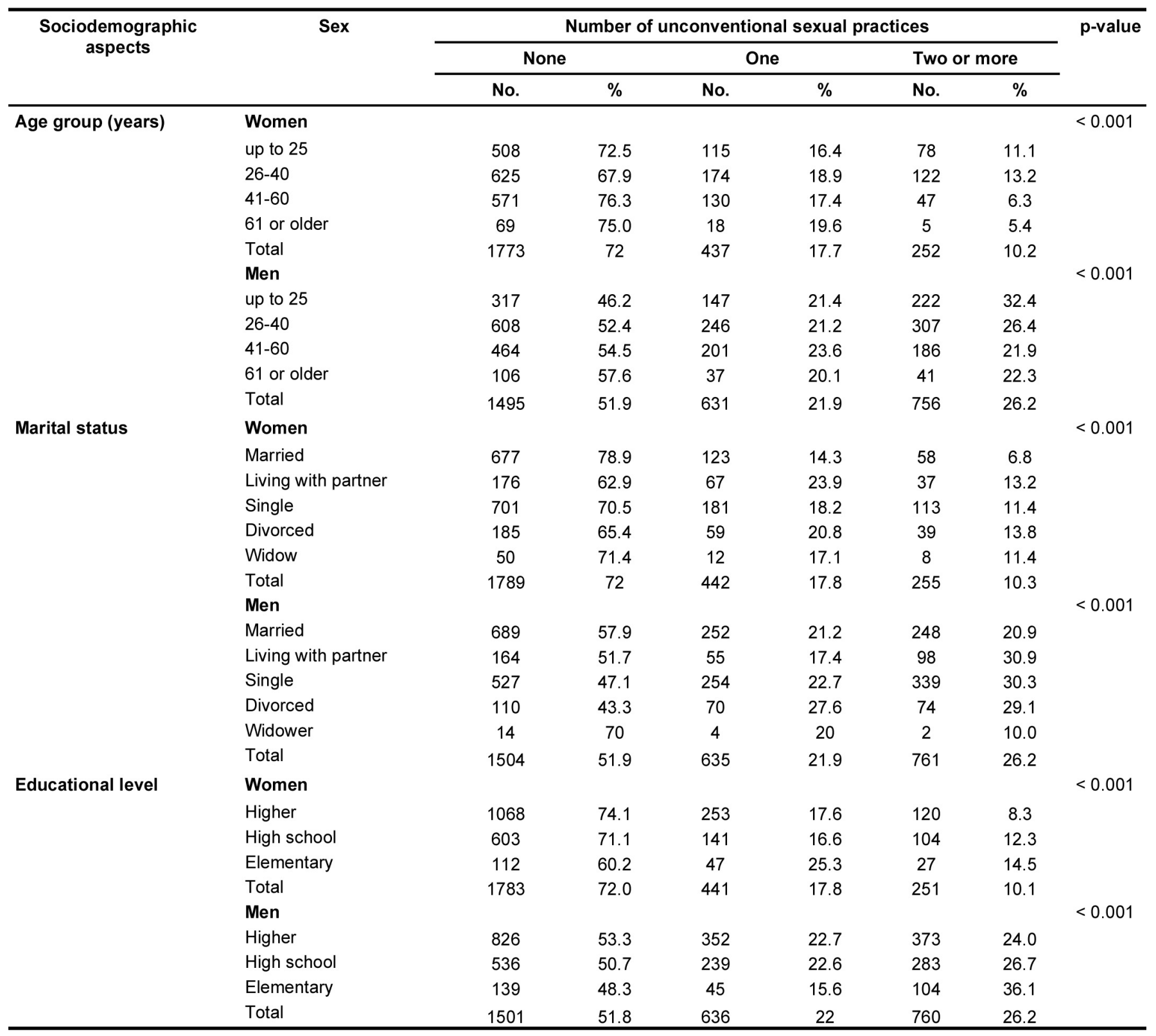

the prevalence of posttraumatic stress disorder in the literature ranges from 5 to $14 \%$ for paraphilias and from 0 to $6 \%$ for SC, ${ }^{17,23}$ which is similar to the rates found in our population of group 1.

In Brazil, ${ }^{5}$ sexual practices less frequent for women and men than vaginal penetration are respectively oral sex (62.4 and 66.8\%) and anal sex (15 and 28.4\%). Such practices are more frequent in group 1, which suggests a need for different ways of feeling pleasure or more sexual stimuli to obtain sexual arousal, since group 1 had more complaints of loss of concentration during sexual activity and group 1 men had more erectile dysfunction. Therefore, USB could be compensating for this sexual difficulty by increasing the repertoire of sexual stimuli in these individuals.

A study conducted with an Australian sample showed that the individuals who reported the practice of sadomasochism (one of the ten USBs investigated in the present study), similarly to those subjects of group 1, had higher chances of having extramarital relationships and practising oral sex more often. In the same study, the authors found that this population also included a larger number of individuals who paid for sex, participated in group sex and masturbated more often than those who did not report sadomasochism. ${ }^{26}$

Aspects suggestive of sexual compulsivity in group 1 (use of "morning after pill" and report of extra-marital relationships) characterize not only risky sex but also indicate sexual hyperactivity. ${ }^{16,27}$

There was higher prevalence of USB in homosexuals and bisexuals. According to the above-mentioned study carried out in Sydney, Australia, homosexual men who engaged in 
unconventional sexual activities were at higher risk of acquiring HIV, probably due to the fact that they looked for partners within particular sexual subcultural contexts. ${ }^{28}$ In the same way as with paraphilias and SC, there was a more frequent history of sexual violence in group $1.20,29$

Although group 1 had higher risk of STD and HIV infections and use of "morning after pill," there was more reference to fear of contracting STD in this group, a fact that can be associated with higher frequency of sexual activity. It can be assumed that, in spite of such fear, individuals in group 1 had unsafe sexual practices due to higher sexual need.

Information and education about sex throughout life may be an important instrument in preventing risky sexual behavior. ${ }^{30}$ It was a protection factor against USB for women in this sample, since those who reported having received guidance on sex during their lives mentioned the practice of USB in $29.3 \%$ of the cases in comparison with $36.7 \%$ of those who had not had sexual education ( $\mathrm{p}=0.003$ ), although cause/effect correlations cannot be assumed in this type of study. Therefore, we suggest that this topic should be further investigated by means of other prospective studies. Guidance and treatment of sexual difficulties at the beginning of sexual life should be an important factor for USB prevention and its negative consequences, since sexual difficulties in early sexual life were associated with presence of USB in adult life.

The logistic regression model indicated the profile of individuals with USB. The typical individual was male, separated or divorced, belonging to the black or mulatto race, with elementary educational level, and bisexual orientation. This individual has a history of psychiatric disorder such as posttraumatic stress, treatment for alcohol dependence and indications of risky sexual behavior: partner's use of "morning after pill". History of sexual difficulties at the beginning of sexual life, sexual violence and high frequency of anal and oral sex were also observed.

What is commonly considered unconventional, in practice proved to have high frequency: more than half of men and about $1 / 3$ of women reported at least one of these experiences throughout their lives. Therefore, there seems to be a diathesis between what is often assumed and what is actually practised in sex. The study showed that the behavioral spectrum of human sexual arousal is wide, being usual to find, in the general population, sexual practices considered unconventional, which are present in paraphilias and SC.

Since the 1940s, with the pioneering study by Kinsey (1948), it has been known that not everything socially commented about sex is actually put into practice. ${ }^{19}$

It can be concluded that an individual is highly likely to report at least one USB throughout life. However, the same individual is much less likely to report multiple USBs. Thus, the situation in which an individual has only one USB throughout life cannot be taken as a diagnosis, since the study revealed that what actually seems to be unconventional is the practice of multiple USBs throughout life. Nevertheless, the mere presence of USB was associated with negative physical, mental and sexual health parameters.

\section{Conclusion}

This study showed that the prevalence of USBs in the Brazilian general population was high. However, the frequency of individuals with multiple USBs was low. Even though these are different conditions, USBs had many negative parameters regarding physical, mental and sexual health that are usually found in paraphilias and SC.

Prevalence of USB was higher in men than in women. Having USB was associated with worse socioeconomic conditions.

Since, according to our findings, USBs were associated with psychiatric disorders and STD, sexual education is necessary not only to prevent STD and HIV but also to avoid the practise of USBs. Strategies of prevention, guidance and early treatment can bring benefits to physical and mental health, since USBs are associated with several negative parameters of mental, physical, and sexual health.

Further studies should be conducted to determine whether USBs can become dysfunctions or not in a certain individual, resulting in a possible diagnosis of SC, paraphilia or other psychiatric disorder.

Specific diagnostic instruments and representative samples of the population can be used to estimate the rates of USB in Brazil. Further studies of the population that reported the practice of multiple USBs throughout life (more than one), but in a recurrent and persistent form, could clarify whether this population has worse health parameters than those found for the population investigated in the present study, as well as to what extent it makes the population with multiple USBs more similar to individuals with paraphilias or SC than the participants of the present study who reported the practice of USBs. 


\begin{tabular}{|c|c|c|c|c|c|c|c|}
\hline $\begin{array}{l}\text { Writing group } \\
\text { member }\end{array}$ & Employment & $\begin{array}{l}\text { Research } \\
\text { grant }^{1}\end{array}$ & $\begin{array}{c}\text { Other research grant or } \\
\text { medical continuous } \\
\text { education }\end{array}$ & $\begin{array}{l}\text { Speaker's } \\
\text { honoraria }\end{array}$ & $\begin{array}{l}\text { Ownership } \\
\text { interest }\end{array}$ & $\begin{array}{l}\text { Consultant/ } \\
\text { Advisory } \\
\text { board }\end{array}$ & Other $^{3}$ \\
\hline $\begin{array}{l}\text { Waldemar } \\
\text { Mendes de } \\
\text { Oliveira Júnior }\end{array}$ & $\begin{array}{l}\text { IPq-HC- } \\
\text { FMUSP }\end{array}$ & * & - & - & - & - & - \\
\hline $\begin{array}{l}\text { Carmita Helena } \\
\text { Najjar Abdo }\end{array}$ & $\begin{array}{l}\text { IPq-HC- } \\
\text { FMUSP }\end{array}$ & * & - & * & - & * & - \\
\hline
\end{tabular}

References

1. American Psychiatric Association - APA. Diagnostic and statistical manual of mental disorders. 3rd ed. rev. Washington: American Psychiatric Association; 1987.

2. Kafka MP, Hennen J. Hypersexual desire in males: are males with paraphilias different from males with paraphilia-related disorders? Sex Abuse. 2003;15(4):307-21.

3. Laumann E, Gagnon J, Michael R, Michaels S. The social organization of sexuality: sexual practices in the United States. Chicago: University of Chicago Press; 1994.

4. Crawford J, Kippax S, Rodden P, Donohoe S, Van de Ven P. Male Call 96: National telephone survey of men who have sex with men. Sydney: National Centre in HIV Social Research; 1998.

5. Abdo CHN. Descobrimento sexual do Brasil. São Paulo: Summus; 2004.

6. Associação Psiquiátrica Americana - APA. Transtornos sexuais e da identidade de gênero. In: APA, organizador. Manual diagnóstico e estatístico de transtornos mentais. Rev. Porto Alegre: Art Med; 2002. p. 511-53.

7. Organização Mundial da Saúde - OMS. Classificação de Transtornos Mentais e de Comportamento da CID-10, descriçôes clínicas e diretrizes diagnósticas. Porto Alegre: Art Med; 1993.

8. Instituto Brasileiro de Geografia e Estatística - IBGE. Sistema IBGE de recuperação automática - SIDRA Dados do censo de 2000. [citado 12 Dez 2009]. Disponível em:www.sidra.ibge.gov.br/bda/popul/

9. Dunne M. Sex surveys: what does it mean when thirty to forty percent don't participate? Venereology. 1998;11(2):33-7.

10. Långström N, Seto MC. Exhibitionistic and voyeuristic behavior in a Swedish national population survey. Arch Sex Behav. 2006;35(4):427-35.

11. Långström N, Zucker KJ. Transvestic fetishism in the general population: prevalence and correlates. J Sex Marital Ther. 2005;31(2):87-95.

12. Udry JR, Billy JO, Morris NM, GroffTR, Raj MH. Serum androgenic hormones motivate sexual behavior in adolescent boys. Fertil Steril. 1985;43(1):90-4.

13. Schiavi RC, Theilgaard A, Owen DR, White D. Sex chromosome anomalies, hormones, and sexuality. Arch Gen Psychiatry. 1988;45(1):19-24.

14. Richters J, Grulich AE, de Visser RO, Smith AM, Rissel CE. Sex in Australia: Autoerotic, esoteric and other sexual practices engaged in by a representative sample of adults. Aust NZ J Public Health. 2003;27(2):180-90.

15. Goodson P, McCormick D, Evans A. Searching for sexually explicit materials on the internet: an exploratory study of college students' behaviour and attitudes. Arch Sex Behav. 2001;30(2):101-18.

16. Stein M, Herman DS, Trisvan E, Pirraglia P, Engler P, Anderson BJ. Alcohol use and sexual risk behavior among human immunodeficiency virus-positive persons. Alcohol Clin Exp Res. 2005;29(5):837-43.

17. Kafka MP, Hennen J. A DSM-IV Axis I comorbidity study of males $(\mathrm{n}=120)$ with paraphilias and paraphilia-related disorders. Sex Abuse. 2002;14(4):349-66.

18. Barbaree HE, Blanchard R, Langton CM. The development of sexual aggression through the life span: the effect of age on sexual arousal and recidivism among sex offenders. Ann NY Acad Sci. 2003;989:59-71; discussion: 144-53.

19. Kinsey AC, Pomeroy WB, Martin CE. Sexual behavior in the human male. Philadelphia: W. B. Saunders; 1948.

20. Coleman E. Is your patient suffering from compulsive sexual behavior? Psychiatr Ann. 1992;22:320-5.
21. Baay M, Verhoeven V, Wouters K, Lardon F, Van Damme P, Avonts D, Van Marck E, Van Royen P, Vermorken JB. The prevalence of the human papillomavirus in cervix and vagina in low-risk and high-risk populations. Scand J Infect Dis. 2004;36(6-7):456-9.

22. Sanchez-Aleman MA, Uribe-Salas F, Conde-Gonzales CJ. Human papillomavirus infection, a possible biological marker of sexual behavior among university students. Salud Publica México. 2002;44(5):442-7.

23. Kafka MP, Prentky RA. Attention-deficit/hyperactivity disorder in males with paraphilias and paraphilia-related disorders: a comorbidity study. J Clin Psychiatry. 1998;59(7):388-96.

24. McElroy SL, Soutullo CA, Taylor P Jr, Nelson EB, Beckman DA, Brusman LA, Ombaba JM, Strakowski SM, Keck PE Jr. Psychiatric features of 36 men convicted of sexual offenses. J Clin Psychiatry. 1999;60(6):414-20.

25. Raymond NC, Coleman E, Miner MH. Psychiatric comorbidity and compulsive/impulsive traits in compulsive sexual behavior. Compr Psychiatry. 2003;44(5):370-80.

26. Richters J, de Visser RO, Rissel CE, Grulich AE, Smith AMA. Demographic and psychosocial features of participants in bondage and discipline, "Sadomasochism" or Dominance and Submission (BDSM): Data from a National Survey. J Sex Med. 2008;5(7):1660-8.

27. Munoz-laboy M, Castellanos D, Westacott R. Sexual risk behaviour, viral load, and perceptions of HIV transmission among homosexually active Latino men: an exploratory study. AIDS Care. 2005;17(1):33-45.

28. Kippax S, Campbell D, Van de Ven P, Crawford J, Prestage G, Knox S, Culpin A, Kaldor J, Kinder P. Cultures of sexual adventurism as markers of HIV seroconversion: a case control study in a cohort of Sydney gay men. AIDS Care 1998;10(6):677-88.

29. Money J. Lovemaps: clinical concepts of sexuallerotic health and pathology, paraphilia, and gender transposition in childhood, adolescence and maturity. New York: Irvington; 1986.

30. Williams CR, Wimberly Y. Sexually transmitted disease prevention in adolescents and young adults. J Natl Med Assoc. 2006;98(2):275-6. 